\title{
FROM TEXTS TO READERS: \\ LITERARY CRITICISM, SOCIOLOGY OF PRACTICE AND CULTURAL HISTORY
}

De textos a leitores: crítica literária, sociologia da prática e história da cultura

De los textos a los lectores: crítica literaria, sociología de las prácticas y historia cultural

ROGER CHARTIER

http://dx.doi.org/10.1590/\$2178-14942017000300012

Roger Chartier is a French historian and historiographer, member of the École des Annales. Since 2006, he has been a lecturer at the Collège de France. He attended the École Normale Supérieure, specialized in cultural history, circulation of books and appropriation of ideas and social and cultural practices of reading in modern Europe. Author of works that can be read in many languages, including Portuguese, his books include: La correspondance: les usages de la lettre au XIXe siècle (1991); Les origines culturelles de la Révolution Française (1999); and Histoire de la lecture dans le monde occidental (2001) (roger.chartier@ehess.fr).

Article received on May $1^{\text {st }}$ and approved for publication on June $1^{\text {st }} 2017$. 


\begin{abstract}
This essay is devoted to two questions. Firstly, it analyzes how reading was conceived by literary criticism, sociology of practices, and cultural history in the end of the twentieth century. What is at stake here is the conceptualization of the relationship between the text and the reader and the process through which meaning is constructed. Secondly, it recalls some fundamental questions raised by the history of reading, not for their own sake but because they can suggest some approaches for the analysis of reading practices in modern times.
\end{abstract}

KeYwORDs: literary criticism; sociology of literature; cultural history; modern Europe; history of reading.

\title{
RESUMO
}

0 presente ensaio se debruça sobre duas questões. Primeiramente, analisa-se como 0 ato de ler foi concebido pela crítica literária, sociologia da prática e história da cultura no final do século XX. 0 que está em jogo aqui é a conceituação da relação entre texto e leitor e o processo pelo qual se constrói o sentido. Em segundo lugar, 0 artigo discute algumas questões fundamentais suscitadas pela história da leitura, não pelas questões em si, mas porque elas podem sugerir algumas abordagens para a análise das práticas de leitura nos tempos modernos.

Palavras-chaVe: crítica literária; sociologia da literatura; história da cultura; Europa moderna; história da leitura.

\section{RESUMEN}

Este ensayo estará dedicado a dos cuestiones. En primer lugar, quisiera analizar la manera en que la lectura fue concebida por la crítica literaria, la sociología de las prácticas y la historia cultural a finales del siglo XX. Lo que estaba en juego aquí era la conceptualización de la relación entre el texto y el lector y el proceso a través del cual se construye el significado. En segundo lugar, me gustaría recordar algunas cuestiones fundamentales planteadas por la historia de la lectura, no por sí mismas, sino porque pueden sugerir algunos enfoques para el análisis de las prácticas de lectura en los tiempos modernos.

Palabras clave: crítica literaria; sociología de la literatura; historia de la cultura; Europa moderna; historia de la lectura. 


\section{TEXTS WITHOUT READERS}

Ater 1945, due to structural or semiotic perspectives that inspired both the English and was considered as produced by the impersonal functioning of language within the works themselves. Hence the critique of the authorial intent and the primacy given to the linguistic machinery of texts. As Wimsatt and Beardsley wrote in their famous article "The Intentional Fallacy", published in 1946 in The Sewanee Review, "there is a difference between internal and external evidence for the meaning of a poem. And the paradox is that what is internal is also public: it is discovered through the semantics and syntax of a poem, through our habitual knowledge of the language, through grammars, dictionaries, and all the literature which is the source of dictionaries, in general through all that makes a language and culture; while what is external is private and idiosyncratic; not a part of the work as a linguistic fact". Consequently, critical inquiries must prefer thus the internal evidence because "a poem can be only through its meaning - since its medium is words". By refusing the "romantic intentionalist assumption", New Criticism did not only deny any relevance to the biography of the author or the circumstances of writing, but also did not give any importance to the readers in their actual diversity since meaning, as exposed by criticism, is the result of a linguistic machinery.

Without authors nor readers, the texts were also thought of lacking materiality. Such perspective echoed, in literary criticism, numerous discourses that postulate the existence of works always identical to themselves regardless of their material forms or interpretive appropriations: hence the Neo-Platonist opposition between the purity of an idea and its corruption by the matter, the justification of the copyright that established the author's property in a text considered to be always the same, whatever the form of its publication, or the triumph of a post-Kantian aesthetics that judged works regardless of their different and successive embodiments.

Paradoxically, the two critical approaches that, after 1945, have born the most sustained attention to the material modalities of the inscription of written words have reinforced rather than combatted this process of textual abstraction. The New Bibliography pioneered by Pollard, McKerrow and Greg and continued by Fredson Bowers, has mobilized the rigorous 
study of the various states of the same work (editions, issues, copies) in order to find an ideal text, purified of the alterations inflicted to it through the process of publication and supposedly in conformity with the text written, dictated, or dreamed of by its author. Hence within a discipline dedicated almost exclusively to the comparison of printed objects, the obsession for lost manuscripts and the radical distinction between the "essentials" of the work and the "accidents" that have deformed or corrupted it. From such perspective, readers did not play any role beyond misreading the authorial intent by scribes, copy editors or compositors.

The deconstructionist approach, in turn, has forcefully insisted on the materiality of writing and the different forms of inscription of language. But in its efforts to abolish or reframe the most immediate oppositions (between orality and writing, between speech acts and the reproducibility of the written word), such approach has proposed encompassing conceptual categories ("archi-writing", "iterability") that divert from the possible perception of the effects produced by the empirical differences that they are effacing. Consequently, the instability of the meaning of texts lies in the contradictory relations between words that constitute language and give to the texts their undecidability, rather than in the diversity of the reader's actual practices.

\section{THE BIRTH OF THE READER}

I $n$ a reaction against this inscription or effacement of the reader within the text, several approaches have considered, since the seventies, the production of meaning as constructed by the inventive and dynamic relationship that exists between readers and texts. The project took on diverse forms within literary criticism and cultural sociology but the main issue was the same: how to free the readers from the tyranny of the authorial intent or the linguistic machinery of texts without falling into an endless inventory of subjective readings. I would like to stress five of the propositions that addressed this challenge.

1. In the theory or poetics of reception, lies the concept of "Erwartungshorizont" or "horizon of expectation" that must overcome the difficulty. In a definition proposed by Hans Robert Jauss in his seminal article "Literary History as a challenge to Literary Theory", published in 1970, the concept refers to the aesthetic and intellectual categories that govern the reception and interpretation of the works by their readers. For Jauss, this horizon of expectation is composed of three fundamental elements: "this frame of reference for each work develops in the historical moment of its appearance from a previous understanding of the genre, from the form and themes of already familiar works, and from the contrast between poetic and practical language". Breaking with the idea of an "objective meaning, determined once and 
for all and directly open to the interpreter at any time", the dialectic relationship between the works and their readers allows to understand why some works immediately fulfilled what their readers expected and why some others (for example, Don Quijote or Madame Bovary) challenged previous categories and were able to impose a "change of horizons".

2. The "reader-response theory" focused on the dynamic interaction between the structure or motives of the texts and the individual reader's work of interpretation and appropriation. From this perspective, reading must be understood as a response to the text. As Wolgang Iser wrote in his book The Act of Reading published in 1978: "Aesthetic response is to be analyzed in terms of a dialectic relationship between text, reader, and their interaction. It is called aesthetic response because, although it is brought about by the text, it brings into play the imaginative and perceptive faculties of the reader, in order to make him adjust and even differentiate his own focus. This approach implies that this book [Iser's book] is to be regarded as a theory of aesthetic response (Wirkungstheorie) and not as a theory of the aesthetics of reception (Rezeptionstheorie). [...] A theory of response has its roots in the text; a theory of reception arises from a history of readers' judgments."

The phenomenology of reading and the theory of interaction are proposed by Iser for refusing "the current theories which give the impression that texts automatically imprint themselves on the reader's mind of their own accord". His starting point is "the fact that the linguistic signs and structures of the text exhaust their function in triggering developing acts of comprehension. This is tantamount to saying that these acts, though set in motion by the text, defy total control by the text itself and, indeed, it is the very lack of control that forms the basis for the creative side of reading". Hence, for example, the stimulation of the reader's imagination by the gaps and negations in the text, the former - the gaps - because they "induce the reader to perform basic operations within the text", the latter - negations or contradictions - because the reader "is guided to adopt a position in relation to the text".

3. For constructing the inventive capacity of reading without postulating multiple arbitrary interpretations, Stanley Fish proposed, in 1980, in his book Is There a Text in this Class? the category of "interpretive communities". Coined for avoiding either the tyranny of the text or the radical solipsism of reading and for resolving "the dilemma between the champions of the text and the champions of the reader", the concept referred to interpretive categories and strategies that are neither universal nor totally idiosyncratic. For Fish, "the act of recognizing literature is not constrained by something in the text, nor does it issue from an independent and arbitrary will; rather, it proceeds from a collective decision as to what will count as literature, a decision that will be in force only so long a community of readers or believers continues to abide by it". The concept of "interpretive community" must allow linking text and readers, 
object and subject, the evidence of meaning and the experience of reading: "An interpretive community is not objective because, as a bundle of interests, of particular purposes and goals, its perspective is interested rather than neutral; but by the very same reasoning, the meanings and texts produced by an interpretive community are not subjective because they did not proceed from an isolated individual but from a public and conventional point of view."

For Stanley Fish, the interpretive strategies displayed by different communities of readers are, at the same time, decisive for the construction of the meaning of what is read and precedes the act of reading because they imply norms and values that govern, for each reading community, its relation with literature and, more broadly, the written culture: "interpretive strategies are not put into execution after reading; they are the shape of reading, and because they are the shape of reading, they give texts their shape, making them rather, than, as is usually assumed, arising from them."

4. It seems to me that we could consider as close to the perspectives proposed by Jauss and Fish, what Barthes wrote in "La mort de l'auteur", an essay first published in English in the Aspen Magazine in 1967 and published in French the following year in the review Mantéia. Barthes defined reading as the position or place where meaning is constructed and evades the author's control or intention: "a text consists of multiple writings, issuing from several cultures and entering into dialogue with each other, into parody, into contestation; but there is one place where this multiplicity is collected, united, and this place is not the author, as we have hitherto said it was, but the reader: the reader is the very space in which are inscribed, without any being lost, all the citations of a writing consists of; the unity of a text is not in its origin, it is in its destination." Hence the dramatic conclusion: "the birth of the reader must be ransomed by the death of the Author".

5. Last but not least, Michel de Certeau's famous metaphor of reading as poaching. For him, reading is not a passive consumption but an active production: "Reading (an image or a text) seems to constitute the maximal development of the passivity assumed to characterize the consumer, who is conceived as a voyeur (whether troglodytic or itinerant) in a 'showbiz society'. In reality, the activity of reading has, on the contrary, all the characteristics of silent production: the drift across the page, the metamorphosis of the text effected by the wandering eyes of the reader, the improvisation and expectation of meanings inferred from a few words, leaps over written spaces in ephemeral dances. The reader insinuates into another person's text the ruses of pleasure and appropriation: he poaches on it, is transported into it, pluralizes himself in it like the internal rumblings of one's body."

For Michel de Certeau, reading is a paradigmatic example of the "ways of operating", these arts de faire which are tactics considered as "art of the weak" that appropriate what 
is imposed by the strategies of different powers - either economic or cultural: "The place of a tactic belongs to the other. A tactic insinuates itself into the other's place, fragmentarily, without taking it over its entirety, without being able to keep it at distance." It is in this sense that readers are travellers: "Far from being writers - founders of their own place, heirs of the peasants of earlier ages now working on the soil of language, diggers of wells and builders of houses - readers are travellers: they move across lands belonging to someone else, like nomads poaching their way across fields they did not write, despoiling the wealth of Egypt to enjoy it themselves." But, like in Barthes's "Death of the Author", it is such poaching that produces the meaning, or even the existence of any text: "Whether it is question of newspapers or Proust, the text has a meaning only through its readers; it changes along with them; it is ordered in accord with codes of perception that it does not control. It becomes a text only in its relation to the exteriority of the reader, by an interplay of implications and ruses between two sorts of 'expectations' in combination: the expectations that organizes a readable space (a literality), and one that organizes a procedure for the actualization of the work (a reading)."

\section{READING PRACTICES AND MATERIALITY OF THE TEXT}

II these approaches have assigned an essential role to reading in the construction of
meaning and have considered that interpretation was a dialogical or dynamical act. But they became the targets of criticism developed by the sociology of texts (as defined by D. F. McKenzie) and cultural history. First of all, they very often considered texts as if they existed in and of themselves, outside objects or voices that transmit them. But we must recognize that the forms which make texts to be read also participate in the construction of their meaning. "Forms effect meaning", wrote McKenzie in his "Panizzi Lectures" in 1985. That is why disciplines dedicated to the rigorous description of objects that carry the texts have regained importance in the last decades, such as paleography and codicology transformed into an ambitious history of written culture by Armando Petrucci, or bibliography converted into sociology of texts by D. F. McKenzie himself.

Secondly, critical approaches that have considered reading as a "reception" or a "response" have implicitly universalized the process of reading as if it had always been a similar act in which circumstances and concrete modalities do not matter. They have also erased the historical and social determinations and variations of reading practices. Barthes did it by affirming that "the reader is a man without history, without biography, without psychology; he is only someone who holds, in a single field, all the paths of which the text is constituted", Jauss, by presupposing that there is a "transsubjective horizon of understanding that determines the 
impact of the text", and Fish, by reducing the characteristics of "interpretive communities" to their sole hermeneutic strategies.

Against this obliteration of the historicity of the reader, history, or the sociology of reading, shows that the meanings attributed to the texts rely on the capacities, conventions, and practices of reading typical of the communities that constitute, simultaneously or successively, their different readerships. Against the presupposition of invariance of reading, whatever the genre it appropriates or the circumstances of practice, Pierre Bourdieu points out in his essay "Lecture, lecteurs, lettrés, littérature" (published in English in 1990 in his book In Other Words) that "to ask about the conditions under which reading is possible is to ask about the social conditions under which the situation in which one reads is possible [...] and also about the social conditions governing the production of lectores [in the medieval sense of the learned, professional, academic readers]. One of the illusions of the lector is to forget his own social conditions of production, unconsciously, to universalize the conditions under which his reading is possible". Consequently, one of the main tasks of literary criticism or cultural history consists precisely of dissipating this illusion. It holds the "world of the text" to be a world of objects and performances, and the "world of the readers" to be the world of the communities to which they belong and that are defined by a series of social and cultural characteristics.

This is why D. F. McKenzie gave fundamental importance to reading in his sociology of texts. McKenzie agrees with the idea that a text actually comes to life only when readers make it their own. But he gives to the axiom a fundamentally historical dimension: "New readers make new texts, and their new meanings are a function of their new forms." This remark pinpoints the double set of variations (in readers' abilities, expectations, and habits; in the material forms in which texts are presented for reading) that any approach must take into account if it hopes to reconstruct how readers produce meaning when they read a text. It is the way to give materiality to the "readable space" mentioned by De Certeau and to locate reading, understood as the "actualization of the work", within its historical and socio-cultural conditions of possibility.

The concept of "materiality of the text" was introduced by Margreta De Grazia and Peter Stallybrass in an article published in Shakespeare Quarterly in 1993. Their critique challenged two dominant modes of reading Shakespeare at the time - formalism and historicism: "Both forms of criticism have taken for granted the identity of their object without realizing how that assumption subverts their very approach. Formalists call for exacting attention to the minutiae of literary language without giving thought to the printing-houses practices that have, in modern editions, produced them. Historicists, tracing in Shakespeare's works the discursive structures specific to the late sixteenth and early seventeenth centuries, have ignored 
the extent to which these structures are eighteenth-century constructs." Their first target was the New Criticism that considered texts as linguistic structures that produce meaning independently from the material inscriptions of the language; the second one was the New Historicism that focused on the negotiations between the work of literature and the social world and on the aesthetic and symbolic appropriation by the works themselves of ordinary objects, languages, and ritual and daily practices, but without historicizing the unstable relations between the works and their multiple texts.

Even if the historicity of reading practices was not the main issue of this twofold criticism, it was implied by the idea that no text exits the material form that offers it for reading or the circumstances in which it is read. As Roger Stoddard wrote, "Authors do not write books. Books are not written at all. They are manufactured by scribes and other artisans, by mechanics and other engineers, and by printing presses and other machines". Paying attention to the material embodiment of texts that results from editorial decisions, technical operations, and labor practices is a powerful way for understanding how, at different times, readers have appropriated the works they have read.

David Kastan has recently characterized the view that a work transcends any possible material incarnation as "Platonic", in contrast to the "pragmatic" view according to which no text exists apart from the material forms and cultural practices through which it is read or heard. These contradictory perceptions of the text divide both literary criticism and editorial practice, opposing those who attempt to restore the author's immaterial intentions by repairing the "wounds" inflicted in the course of copying and typesetting the work to those who argue that we must respect and understand the irreducible diversity of a work's historical states.

A similar tension between the immateriality of texts and the materiality of books also characterizes the relations between readers and the texts that they appropriate. In his lecture "El libro", "The Book", delivered in 1978, Jorge Luis Borges said: "One day I thought I would write a history of the book." But he added immediately: "I am not interested in the physical aspect of books [...] but in the various ways in which books have been regarded." For Borges, thus, the material form of the text is irrelevant; what counts is how a "book", meaning the abstract literary work independently of its form, was regarded, or, often, disregarded, in comparison with the "winged and sacred" spoken word. Borges, in other words, took the "Platonic" view.

But when the same Borges dictated his autobiography to Norman Thomas di Giovanni (published in The New Yorker in 1970), he spoke quite differently about one of the books that had shaped his life: Don Quijote de la Mancha. Now, he vividly recalls the specific object that he had held in his hands and read: "I still remember the red bindings with gilt titles of the 
Garnier edition. Eventually, after my father's library was broken up and I read Don Quijote in another edition, I had the feeling that it was not the real Don Quijote. Later, a friend obtained for me a Garnier copy with the same engravings, the same footnotes and the same errata. For me, all these things were part of the book: in my mind, this was the real Don Quixote." For Borges, the "real" Don Quixote took the irreducible material form of an illustrated edition that had been imported from France, the edition that he had read as a young boy. The Platonic principle is of little weight compared with the pragmatic return of memory.

Borges' two contradictory views suggest that the contrast between "Platonism" and "pragmatism" is perhaps missing a decisive element in reading experience. On the one hand, a text, whatever it may be, becomes always available to be read or heard only in some particular material form. Depending on time and genre, the variations between these different states of the "same" text can involve, separately or together, the modalities of its inscription and publication, the spelling of the words and the layout of the page, or textual variants. On the other hand, multiple agencies — philosophical, aesthetic, juridical — attempt to reduce this diversity by postulating the existence of a work that remains the same regardless of its variations. They construct an ideal text, which readers recognize in each of its different states. What is important is not to resolve this irreducible tension but, rather, to identify the way in which it was thought of at various moments and by different communities of readers. This project was a founding principle for the development of the history of reading practices.

\section{READING AS PRACTICE}

To illustrate the uses historians had made of the reflections about reading developed by literary criticism or cultural sociology, I would like to stress four fundamental transformations of reading practices in the Western societies between the late Middle Ages and modern times and, in doing this, I suggest some topics for questioning contemporary times.

1. The first transformation considers reading as a corporeal experience related to the body and the voice. Reading has become a silent and visual appropriation of the texts at the expenses of reading out loud that was necessary for understanding the texts read. Even if the chronology of such mutation can be discussed, the thesis that emphasizes the progressive diffusion of silent reading accurately refers to a profound mutation of the experience of reading. Michel de Certeau underlined the effects of such transformation: "To read without uttering the words aloud or at least mumbling them is a 'modern' experience, unknown for millennia. In earlier times, the reader interiorized the text; he made his voice the body of the other; he was its actor. Today, the text no longer imposes its own rhythm on the subject, it no longer 
manifests itself through the reader's voice. This withdrawal of the body, which is the condition of autonomy, is distancing from the text. It is the reader's habeas corpus."

For Paul Saenger, the conquest of silent reading was the result of gradual advances of the possibility of the practice first in the monasteries of the early Middle Ages, then during the twelfth and thirteenth century in schools and universities, and finally, in the last centuries of the Middle Ages among the lay aristocracy. Later, the capacity of reading visually and silently was expected from all the readers, even the most popular ones. Armando Petrucci challenged this diachronic model by stressing that several modalities of reading coexisted in the medieval period and were practiced either by different readers or by a single reader: silent reading, reading in a low voice, called "ruminatio", which served as an aid for meditation and an instrument for memorization, and finally reading out loud which was rather like liturgical recitation and chanting. What remains, however, is the fact that the progress of literacy defined as a universal norm enables readers to read without the need to listen to the text. As a consequence, the necessity of reading aloud for understanding a text became characteristic of illiteracy. Silent reading initiated a relation with the written word that was more secretive and permitted a rapid, skilled reading that could decipher the multiple relationship set up between the discourse and its glosses, commentaries, tables and index.

If the history of reading in the longue durée is, as Certeau wrote, the history of the conquest of the reader's freedom, the modality of reading, be it vocal or visual, is not the only transformation of reading as a bodily experience to be considered. Reading a scroll in the Antiquity required the mobilization of the entire body: the scroll must be held using one's both hands, and the reader, in this case, cannot write while reading. The invention and diffusion of the codex between the second and fourth centuries of the Christian era freed the reader who is not obliged to hold the book and can write while reading. The reader can distance himself from a book sitting on a desk or on a pulpit. In the eighteenth century, the multiplication of small formats (octavos, in-12, in-16) allowed familiarity with the books and new practices of reading: reading while walking, reading in the garden or in the countryside, reading in bed, etc.

What happens to the relationship between the body and the text in the digital world when it is mediated by a keyboard or when the reader's fingers move through the text on the screen?

2. A second question concerns reading as writing. During the Renaissance, reading practices cannot be separated from the dominant intellectual technique of common placing. To read was to extract from the texts historical or natural facts, rhetorical models or, mainly, sentences that are sublime universal truths. The reader must mark them on the book itself, then, copy them on a common-place notebook in order to reuse them in his or her own 
compositions. From the eighteenth century, with the decline of common placing, marginal annotations acquired a different meaning: they indicated intellectual or sentimental reactions or response of the readers, who entered into a personal dialogue with the text. This example shows how morphological similarities (to write marginalia on a book) can have very different cultural meanings according to what is expected from reading.

Today, this discontinuity exists even within apparent continuities. Digital reading is a segmented reading, attached to the fragment more than to the totality of the work. Is this not, by the same token, in a direct line of descent from the practices allowed and encouraged by the codex? It is the codex, rather than the screen, that invited the reader to skip pages or passages, to leaf through the book, to read, as Montaigne, "à sauts et gambades", "by skips and jumps" as translated by Florio. It is the codex, rather than the screen, that invited to compare passages on the same book, just as in the typological reading of the Bible, or to indicate, extract and copy citations as demanded by the humanistic technique of common placing. More broadly, written culture and reading experience have been largely and durably constructed on the basis of fragments gathered in collections of commonplaces, anthologies of extracts (often called "esprits" in the eighteenth century), or pedagogical "morceauxchoisis".

It is true but it seems to me that the anthological structure of texts and the fragmentation of reading do not have the same meaning when they are accompanied by the perception of the textual totality made visible by the materiality of the book and when the screen no longer displays the limits and the coherence of the work from which the fragment is extracted. Hence the fundamental question that springs from this radical rupture: how are we to preserve the ways of reading that construct meaning on the basis of the coexistence of various texts in a single and particular object (a book, a journal, a newspaper), when the mode of transmission of the written word imposes an analytical and encyclopedic logic in which every fragment has no other context than a thematic one?

What is at stake here is no less than the dissociation between, on the one hand, the categories that have founded an order of discourse, or reading, in the author's name, the perpetuated identity of works, and the concept of intellectual and literary property and, on the other hand, abandonment of these criteria to the benefit of a new way of reading texts and perceiving the written word as a continuous discourse in which the reader transformed in writer or "wreader" freely recomposes mobile and authorless fragments.

3. Another topic discussed by historians was the question of the "reading revolution" of the eighteenth century. There are two aspects to this question. The first is historical and bears contemporary diagnoses of the morally beneficial or physically disastrous effects of captivation of readers by fiction. Using categories drawn from sensualist psychology, these 
diagnoses reformulated old denunciations of the perils faced by readers of works of fiction. In the Golden Age Castille, for example, three elements were strongly linked: repeated mentions of Plato's expulsion of poets from the Republic; use of the vocabulary of rapture (embelesar, maravillar, encantar) to characterize the fable reader's contempt or denial of the real world; and the idea that the turn to silent, solitary reading at the expenses of reading out loud to others or to oneself encouraged confusion between the world of the text and the world of the reader.

In the eighteenth century, the discourse was medical: a pathology was constructed in which "excessive reading" figured as an individual malady or collective epidemic. Uncontrolled reading was considered dangerous, because it combined physical immobility with stimulation of the imagination. This led to illnesses of the worst sort: engorgement of the stomach and intestines, derangement of the nerves, physical exhaustion. Professional readers, namely men of letters, were most vulnerable to such disorders, all of which could lead to their characteristic affliction, hypochondria. Furthermore, solitary reading could lead to rejection of reality, and preference for the chimerical. Excessive reading was linked to solitary pleasures. Both practices resulted in the same symptoms: pallor, anxiety, prostration. The danger was most severe when reading a libertine or erotic novel, and when the reader was a woman withdrawn into solitude. It might be objected that the generous emotion spurred by the reading of Richardson or Rousseau's novels had nothing in common with the lascivious rapture denounced by physicians. But in both cases reading was conceived in terms of its physical effects. This somatization of a practice traditionally described in terms of intellectual or moral categories was perhaps the first sign of a major mutation, if not of behavior, then at least of representations.

A second aspect of the eighteenth-century "revolution in reading" is historiographical in nature. It is connected with the hypothetical opposition between a traditional form of reading, called "intensive", and a modern form, characterized as "extensive". According to this dichotomy, first proposed by Rolf Engelsing in 1970, the intensive reader faced a limited corpus of texts, which were read and re-read, memorized and recited, heard and learned by heart, and transmitted from generation to generation. This type of reading was deeply imbued with a sacred character and subjected the reader to the authority of the text. The "extensive" reader, who first appeared in the second half of the eighteenth century, was quite different: he read numerous printed texts, many of which were new and ephemeral, and consumed them avidly and rapidly. His gaze was detached and critical. Thus a communal and respectful relation to the (supposedly) written word gave way to a more irreverent and casual mode of reading.

Historians' reactions to this thesis have varied. Without a doubt, Robert Darnton has been the most skeptical of whether this revolution ever took place: "Although tastes changed 
and the reading public expanded, the experience of reading was not transformed. It became more secular and more varied, but not less intense. It did not undergo any revolution. Historians have discovered and dismissed so many hidden revolutions of the past that the 'reading revolution' might be safely ignored." Critical of the expression but sensitive to the mutations in practice, Hans Erich Bödeker offers a nuanced judgment: "Although it is possible to doubt aspects of the 'revolution in reading' hypothesis, a transformation of reading habits did indeed take place at the end of the eighteenth century." Reinhart Wittmann is more categorical: "Was there a reading revolution at the end of the eighteenth century? ... In spite of all the limitations, the answer to the question is yes." Thus it would seem worthwhile to return once more to this debate.

The reading of Richardson's novels or the reading of Rousseau's Nouvelle Héloise radically undermines Engelsing's proposed chronology. The eighteenth-century novel took hold of its reader, captivated him, governed his thoughts and actions. It was read and re-read, quoted, and recited. The reader was invaded by the text and through identification with the heroes of the story he began to decipher his own life in the mirror of fiction. This particularly intense and "intensive" form of reading engaged the entire sensibility of readers, male and female alike, who could not restrain their emotion or tears. This leads us to question the validity of a sharp opposition between two styles of reading, one supposedly following and supplanting the other.

Is that enough, however, to invalidate the idea of a "reading revolution" in the eighteenth century? Perhaps not. Throughout enlightened Europe, profound changes transformed the production of printed work and the conditions of access to books despite the stability of typographic technology and labor. Everywhere, the growing supply of books, the secularization of the titles on offer, the circulation of prohibited books, the proliferation of periodicals, the triumph of small formats, and the proliferation of reading societies and circulating libraries that made it possible to read books and periodicals without buying them allowed and imposed new ways of reading. For the most literate readers of both sexes, the possibilities of reading seemed to expand, paving the way to a variety of practices and experiences associated with different times, places, and genres. Each reader was then at one time or another either "intensive" or "extensive", absorbed or casual, studious or amused. Why not assuming that the eighteenth-century "revolution in reading" consisted precisely in this newfound capacity to read in a variety of ways? This formulation explains the complex nature of the revolution, which is characterized not by the general adoption of a new hegemonic and distinctive style of reading but rather in the recourse to a variety of practices, some of which were old, others new. An "intensive" reader of Richardson, Diderot was also a learned, avid, and ironic reader-and many other things. 
Is it not the case of the readers after 1945, who were the heirs of the mutations that appeared in the eighteenth-century and were reinforced during the two following centuries by the "feuilleton revolution" and the "paperback revolution"? Is it not the case of the digital readers who can jump from one text to another on the same screen or go from one screen to another on the same day?

4. The last tension that leads to the present: between reading in solitude and reading in sociability. If reading was often described as a withdrawal of the reader from the constraints of the family, the office, or the city, reading aloud for others was also a dominant element in multiple forms of sociability, whether familial, institutional (university, college, academies, literary societies), or more spontaneous sociability (while travelling, in the streets or squares). In the eighteenth century, both practices can sustain the construction of a public sphere thought of either as based (as in the Ancient cities) on the oral delivery of speeches and oral exchanges - that is why Franklin imagined various procedures for the reproduction of oral performances — or as defined by the circulation of ideas and opinions resulting from private reading and written communication. It is the participation of the reading public in the discussion about errors, judgments and reforms that defined, for Kant, the public and critical use of their reason by private individuals. In Was Ist Aufklärung?, Kant wrote: "By 'public use of one's reason' I mean that use which a man, as a scholar, makes of it before the reading public."

Kant proposed a new articulation of the relation of the public to the private, not only by equating the public exercise of reason with judgments produced and communicated by individuals acting "in their quality of learned men", but also by defining the public sphere as the sphere of the universal and the private as the domain of particular or "domestic" interests (which may even be those of a church or a state). For that reason, Kant associated the "public use of one's reason" with the production and reading of written texts, rather than with the new forms of intellectual sociability such as literary societies, masonic lodges, clubs, or coffee houses, because they retained something of a "domestic congregation". He did not define the "public" in reference to the ideal of the city in classical antiquity, which presupposed the physical proximity and common deliberation of all the members of the body politic. For him, only written communication and a reading public were a possible figure of the universal.

Did the "reading public" construct a political public sphere after the Second World War or did they deceive Kant's aspiration? And in the digital age is such a public critical and free, or manipulated and alienated? I leave the answers to you. 
